\title{
Racialização e mundos do trabalho na Província do Amazonas: $O$ padre Pardo Daniel Pedro Marques de Oliveira.
}

\section{Racialization and Worlds of Labour in Amazonas Province: the brown Father Daniel Pedro Marques de Oliveira.}

\author{
Tenner Inauhiny de Abreu. ${ }^{1}$
}

\begin{abstract}
Resumo
O presente artigo tem por objetivo apresentar a trajetória do padre pardo Daniel Pedro Marques de Oliveira e a partir de sua atuação política e sacerdotal desnudar o processo de racialização presente na Província do Amazonas durante a segunda metade do século XIX. As experiências do cativeiro e a tentativa de mobilidade social por parte do sacerdote demonstram as estratégias de trabalhadores cativos ou livres marcados pela sua origem racial. O uso dos jornais como fonte principal e de fontes oficiais (relatórios, falas e exposições de presidentes de província) nos ajudam com uma massa documental seriada e que trata das experiências dos indivíduos na sociedade amazonense dos oitocentos.
\end{abstract}

Palavras-chave: Escravidão, Jornais, Racialização.

\section{Abstract}

This article aims to present the history of the brown Father Daniel Pedro Marques de Oliveira and, from its political and priestly action, expose the process of racialization in Amazonas Province during the second half of the nineteenth century. The priest experience on captivity and his attempts to social mobility shows the strategies of captive or free workers marked by their racial origin. The use of newspapers as the main source and official sources (reports, speeches and statements of provincial presidents) help us with a mass and serial documentary that deals with the experiences of individuals in the eighties Amazonas society.

Keywords: Slavery, Newspapers, Racialization

Artigo recebido em:16/01/2014

Artigo aprovado para publicação em: 22/02/2014

\footnotetext{
${ }^{1}$ Mestre em História pela Universidade Federal do Amazonas. Professor Assistente na Universidade Estadual do Amazonas. Vinculado ao Núcleo de Pesquisa de Migração e Africanidades Caribenhas e Latino-Americanas. Email: tabreu@uea.edu.br Este artigo faz parte do projeto de pesquisa "História, Arquivo e Memória de Tefé" e conta com o financiamento da Fundação de Amparo à Pesquisa do Estado do Amazonas - FAPEAM (Projeto Pró-acervo)

Revista Eletrônica da ANPHLAC, ISSN 1679-1061, n. 16, p. 85 - 114, Jan./Jul. 2014.

http://revista.anphlac.org.br
} 


\section{Introdução}

A história de africanos e seus descendentes no Amazonas começa a passar por uma nova fase: pesquisas recentes desnudam a trajetória dos afro-descendentes na sociedade amazonense dos oitocentos. Paira sobre a trajetória de homens e mulheres negros da região uma poderosa (e arraigada) força discriminatória que oculta a importância das culturas africanas para a formação política e social amazonense. Estas curtas páginas se propõem a lembrar, o que a muitos interessa esquecer: a inegável presença e influência de africanos e seus descendentes em nossa formação.

Comecemos pelo ilustre e desconhecido, deputado provincial, Daniel Pedro Marques de Oliveira, homem negro, cuja trajetória se pautou pela proteção aos fugitivos do cativeiro, pela denúncia de senhores violentos, pelo incentivo à emancipação e por inúmeras depreciações de cunho racial, sofridas durante sua vida pública. Antes, se faz necessário dizer que a presença africana na Amazônia está ligada ao drama da escravidão e do infame comércio de almas que se inicia no século XVII e atinge o XIX. Entretanto, a população negra do Amazonas não era formada apenas por escravizados. Na segunda metade do século XIX, por exemplo, mais de $80 \%$ de homens e mulheres negros da província eram livres (entre nascidos livres e alforriados). Dentre estes, estava o vigário Daniel, padre e professor de primeiras letras na Vila de Silves.

\section{1 - O uso do jornal como fonte para análise histórica do Amazonas Provincial.}

O jornal era, no século XIX, um veículo relativamente eficiente de comunicação, cumprindo um importante papel. Essa imprensa já foi classificada como "áulica”, ou seja, se limitava, a publicações governamentais das Províncias e do Império. Essencialmente alguns periódicos eram atrelados ao governo, na medida em que, este necessitava de uma tipografia para reproduzir documentos oficiais. Curiosamente a imparcialidade era tema de destaque dos editoriais e reportagens, mas o que se via na verdade era a imparcialidade sendo posta em segundo plano, apoiavam claramente um ou outro governo, ou davam uma versão restrita dos fatos narrados.

Revista Eletrônica da ANPHLAC, ISSN 1679-1061, n. 16, p. 85 - 114, Jan./Jul. 2014. http://revista.anphlac.org.br 
Durante o denominado período provincial no Amazonas (1850 -1889), Manaus conheceu uma variedade significativa de jornais ${ }^{2}$, entretanto, como principal característica, estes periódicos possuíam vida bastante efêmera. A compreensão da relevância destes jornais no cotidiano das pessoas no período imperial é de fundamental importância para que possamos desnudar a trajetória do padre Daniel Pedro, na medida em que foi nos jornais que este personagem apareceu com suas contradições no universo escravista do Amazonas dos oitocentos.

Abaixo observemos uma tabela contendo a quantidade de jornais distribuídos pelas décadas de 1850 a 1880 na Província do Amazonas:

Tabela 1 - Jornais Editados no Período Provincial no Amazonas - 1851- 1889

\begin{tabular}{|l|r|r|r|r|r|r|r|r|}
\hline \multicolumn{9}{|c|}{ Ano } \\
\hline 1850 & & 1860 & & 1870 & & 1880 & & \\
\hline 1851 & 1 & 1861 & 1 & 1870 & 3 & 1880 & 3 & \\
\hline 1852 & 1 & 1862 & 1 & 1871 & 2 & 1881 & 3 & \\
\hline 1859 & 1 & 1863 & 2 & 1872 & 1 & 1882 & 9 & \\
\hline & & 1866 & 2 & 1873 & 4 & 1883 & 1 & \\
\hline & & 1867 & 2 & 1874 & 3 & 1884 & 7 & \\
\hline & & 1868 & 3 & 1875 & 1 & 1885 & 6 & \\
\hline & & 1869 & 6 & 1876 & 3 & 1886 & 9 & \\
\hline & & & & 1877 & 2 & 1887 & 5 & \\
\hline & & & & 1878 & 5 & 1888 & 15 & \\
\hline & & & & 1879 & 1 & 1889 & 17 & \\
\hline TOTAL & 3 & & 17 & & 25 & & 75 & 120 \\
\hline
\end{tabular}

Elaborado pelo autor. Fonte: Faria e Souza, J. B. A Imprensa no Amazonas, 1851- 1908. Manaus, Tipografia da Imprensa Oficia, 1908, p. 77.

Conforme ressalta Heloísa Cruz, o jornal não nasce pronto “(...) seus conteúdos e formas, sobre como deve ser feito e o que deve conter um determinado jornal ou revista são negociados social e culturalmente num espaço conflituoso, sobre o fazer imprensa a cada momento histórico" (2007, p. 259).

Compreende-se, portanto, a imprensa como prática social e como momento de constituição/instituição dos modos de viver e pensar. Sandra Jatahy Pesavento (2001)

\footnotetext{
${ }^{2}$ Ao todo de acordo com Faria e Souza o período provincial no Amazonas contou com 120 jornais. Entre 1850 e 1908, de que trata a obra do autor, o Amazonas possui cerca de 370 jornais.

Revista Eletrônica da ANPHLAC, ISSN 1679-1061, n. 16, p. 85 - 114, Jan./Jul. 2014. http://revista.anphlac.org.br
} 
assinala que os jornais do século XIX constroem um discurso a respeito da questão social, onde aparecem os tipos perigosos e os usos do espaço urbano. A investigação do periodismo como prática e ação cultural pressupõe o rompimento com concepções restritivas. O periodismo seria, para Maria Luíza Ugarte (2001), indissociável do contexto social do qual faz parte.

No nosso entendimento o uso do jornal, passa pela recuperação do conceito de cultura $^{3}$ dentro da perspectiva da história social. Na visão de Lilia Schwarcz (2008) os jornais são concebidos como produtos sociais, logo, socialmente reconhecidos como objeto de expectativas e representações específicas. A seleção do jornal enquanto documento básico é significativa, na medida em que seu uso como fonte histórica é bastante complexo e completo, pois aí observa-se a convergência de opiniões e posicionamentos políticos.

Um aspecto importante a se destacar é que o discurso presente nos jornais pretendia construir uma sociedade onde não existiam conflitos sociais, o discurso civilizatório apagava um passado de barbárie que insistia em aparecer nos traços indígenas ou de afro-descendentes, contraditoriamente presentes nas páginas dos jornais.

Presentes em páginas secundárias, como infensos a ordem e a civilização, escravos, africanos livres, negros libertos e toda uma gama de trabalhadores e trabalhadoras "não-brancos", mesmo sob uma ótica de um discurso elitista e excludente, os jornais expõem suas experiências, na medida em que aparecem em anúncios de fuga, venda, compra e aluguel de escravos, editoriais ao se reclamar a respeito dos atos de barbárie de índios, ou mesmo nos relatórios da repartição de polícia, que mostram conflitos entre estes trabalhadores.

Todas estas contradições, existentes nos jornais, nos remetem ao historiador britânico Edward Thompson (1998), na medida em que em uma de suas obras mais

\footnotetext{
${ }^{3}$ Ressalta-se o caráter polissêmico do conceito de cultura. Para Maria Luíza Ugarte, o termo cultura era comumente utilizado como uma projeção invertida da base econômica ou ainda como mera derivação desta. Para Déa Fenelon, a cultura dentro dessa perspectiva era entendida como uma produção das coisas do espírito e das ideias, distanciando-se da correlação da sociedade. A base de discussão sobre a teoria da cultura vem da disposição de aceitá-la como processo social, modelando modos de vida globais e não apenas considerá-la como uma teoria das artes e da vida intelectual em relação com a sociedade. Cf. Déa Ribeiro, Fenelon. Cultura e História Social: Historiografia e pesquisa. Projeto História. São Paulo. 10. Dezembro de 1993; Cf. Maria Luíza Pinheiro Ugarte. Folhas do Norte. Letramento e periodismo no Amazonas (1880-1920). PUC-SP Tese de doutorado. São Paulo 2001.
}

Revista Eletrônica da ANPHLAC, ISSN 1679-1061, n. 16, p. 85 - 114, Jan./Jul. 2014. 
relevantes Costumes em comum trata da relação, ou melhor dizendo, de uma releitura entre a cultura, os costumes do povo, poder e a busca de hegemonia. Para o autor, a cultura seria um espaço dinâmico onde ocorreriam trocas entre setores da sociedade. Ao se aproximar de uma perspectiva mais antropológica de cultura e questionar a ideia de que cultura seria um conjunto de valores ${ }^{4}$, a partir de Thompson (1998), podemos destacar de que forma as classes sociais se relacionavam com essa cultura de elite que aparece nos discursos dos jornais da Província.

A perspectiva de apagar a herança dos povos indígenas e a experiência de negros e afro-descentes, a partir de um discurso civilizatório presente nas páginas dos jornais, nos remete novamente a Thompson (1998), na sua obra já mencionada, onde este demonstra como setores populares viviam na Inglaterra do século XVIII e mantinham uma cultura ligada a costumes (entendidos pelo autor como uma interface da lei) que não se subordinava a ideologia dos governantes. Neste contexto pode-se ressaltar a concepção de hegemonia cultural imposta por estes governantes da Inglaterra do final do XVIII e que a vida apesar da apropriação dos setores populares em relação a uma cultura de elite e a existência de uma cultura plebeia, esta última era independente e composta de maneira efervescente, representada por costumes, valores, modos de vida, lazer e trabalhos específicos.

Interessa-nos aqui o conceito de hegemonia cultural para entender as relações entre a elite e o povo, entre classes distintas de origem multiétnica, que constituíam a sociedade amazonense dos oitocentos. Nas páginas dos jornais a trajetória de indivíduos que tinham suas experiências relatadas a partir da ótica do vencedor, indivíduos como o padre Daniel Pedro Marques de Oliveira, nos apontam caminhos diferenciados que nos fazem questionar a respeito da visão que se construiu ideologicamente, sob a sociedade amazonense, onde negros, índios e mestiços deveriam ser civilizados a partir da ótica do trabalho.

\footnotetext{
${ }^{4} \mathrm{~A}$ respeito do conceito de Cultura Thompson afirma: "uma cultura é também um conjunto de diferentes recursos, em que há sempre uma troca entre o escrito e o oral, o dominante e o subordinado, a aldeia e a metrópole; é uma arena de elementos conflitivos, que sob uma pressão imperiosa - por exemplo, o nacionalismo, a consciência de classe ou a ortodoxia religiosa predominante - assume a forma de um sistema. E na verdade o próprio termo "cultura", com sua invocação confortável de um consenso, pode distrair nossa atenção das contradições sociais e culturais, das fraturas e oposições existentes dentro de um conjunto." (2004, p.17)
}

Revista Eletrônica da ANPHLAC, ISSN 1679-1061, n. 16, p. 85 - 114, Jan./Jul. 2014. 
Importante para nossa análise é o conceito de experiência desenvolvido por Thompson, onde este buscava trazer à tona a visão de mundo, a cultura, o cotidiano na história. $\mathrm{O}$ autor afirma que homens e mulheres são retomados como sujeitos dentro do conceito de experiência, não como sujeitos autônomos, livres, mas como pessoas que experimentam suas situações e relações produtivas. Essas experiências ainda de acordo com o autor, sua cultura e suas expressões agiriam sobre determinadas situações (1981, p. 3).

Nos Jornais do século XIX, buscamos compreender as relações sociais entre os distintos grupos que constituíam a sociedade naquele período. A partir desta fonte podemos compreender a existência e uma gama de ideias que reforçam uma mentalidade escravista e em diversos aspectos o fenômeno da racialização no Amazonas.

O discurso presente nos jornais assume interesses de grupos e facções (alguns jornais claramente vinculados à causa abolicionista, outros vinculados a grupos políticos, seja o Partido Conservador, seja o Partido Liberal) o que permite a percepção das tensões e conflitos que permeiam a sociedade.

\section{O Periodismo na Província do Amazonas - 1850-1889.}

O primeiro jornal da então Província do Amazonas foi o "Cinco de Setembro". Teve sua primeira edição lançada em 03 de maio de 1851 circulou até 07 de janeiro de 1852, sendo substituído pelo Estrella do Amazonas, tendo ambos como fundador Manoel da Silva Ramos. O Estrella do Amazonas reconhecia já em seu primeiro editorial a dependência em relação ao poder local: "Contamos com a coadjuvação dos briosos amazonenses e esperamos merecer a alta proteção do Exm $^{\text {mo }}$ Governo da Província, sem a qual não podemos continuar”.

Nos primeiros anos da Província do Amazonas, a quase totalidade da impressão dos relatórios oficiais era feita sob encomenda fora do Amazonas. A tipografia criada por Silva Ramos não dava conta da demanda oriunda da administração provincial. Tal fato demonstra tanto a precariedade dos primeiros anos do periodismo na Província, quanto às ligações estreitas deste setor com a esfera da política dominante.

Revista Eletrônica da ANPHLAC, ISSN 1679-1061, n. 16, p. 85 - 114, Jan./Jul. 2014. http://revista.anphlac.org.br 
Apenas a partir de 1867 é que as Falas e Exposições dos Presidentes de Província passaram a serem impressos em Manaus.

O poder público recorria à tipografia do Jornal Amazonas, de propriedade do português Antônio da Cunha Mendes. Em 1874 existiam três tipografias (relacionadas aos jornais de maior circulação) dentre eles Commércio do Amazonas e Diário do Amazonas em 1874.

Entre 1851 e 1880, este primeiro grande momento do periodismo no Amazonas é caracterizado por Maria Luíza Pinheiro como de lenta expansão. Primeiro surge o Cinco de Setembro que logo depois se transforma em Estrella do Amazonas. Em 1859 surgiu o periódico Vigilante, segundo O Catechista em 1860 e O Progressista em 1862 e O Amazonas, que foi até 1866, o maior diário publicado em Manaus.

Os jornais apresentam neste período, em suas páginas uma série de textos, dentre eles descrições de anúncios de fuga, matérias envolvendo a compra, venda de escravos, brigas pessoais e políticas, prisões realizadas naquele espaço de tempo, enfim uma série de informações valiosas a respeito tanto do universo da escravidão quando dos mundos do trabalho, que na visão de Lilia Schwarcz eram descrições que refletiam e representavam percepções e valores da época. Essa postura diante dos jornais, enquanto fonte é a de apreendê-los não meramente como expressão da verdade ou como veículo imparcial de transmissão de informações, mas antes era uma das maneiras como determinados segmentos sociais produziam, refletiam e representavam percepções e valores a cerca da sociedade em que viviam (2008, p. 17).

Os negros passam a figurar e a frequentar constantemente as seções dos jornais da época. Através destes fragmentos de textos da imprensa (noticiários, editoriais, obituários e ocorrências policiais) podemos reconstituir as várias visões com que se falou a respeito da condição negra. Como podemos observar os jornais são concebidos como produtos sociais, portanto, socialmente reconhecidos e como objeto de expectativas e representações específicas.

Dentre os jornais que nós utilizamos como maior frequência estão o Estrella do Amazonas e $O$ Catechista, devido suas informações apresentarem de maneira mais assídua dados a respeito do universo escravista na Província durante as décadas de 1850 e 1860 e principalmente porque as disputas políticas nas quais se envolveu o padre Daniel aparecem no jornal $O$ Catechista.

Revista Eletrônica da ANPHLAC, ISSN 1679-1061, n. 16, p. 85 - 114, Jan./Jul. 2014. http://revista.anphlac.org.br 
O Jornal Estrella do Amazonas circulou pela primeira vez na Província do Amazonas em 1852. Seus últimos exemplares circularam pela capital do Amazonas 1866. Era um periódico semanal tendo as quartas-feiras como o dia de circulação. Contava com quatro páginas, cada uma delas divididas em duas colunas com seções diversas. Possuía como logotipo o brasão das "armas do Império", e foi lançado no formato $18 \times 26 \mathrm{~cm}$ (SANTOS, 1990).

$O$ Catechista era periódico divulgador das atividades administrativas seguindo o mesmo perfil do jornal Estrella do Amazonas. Pretendia-se, entretanto um jornal mais crítico, independente e imparcial no que diz respeito aos problemas da Província. Era um caderno semanal, tendo como subtítulo "Folha Comercial", contendo quatro páginas divididas em três colunas. Foi lançando com $21 \times 31 \mathrm{~cm}$ de tamanho. O primeiro número é de março de 1871. Este periódico exerceu grande influência política na época de sua edição, conforme assinala Santos (1990).

Os jornais quase não apresentavam ilustrações e os poucos desenhos referiamse a remédios miraculosos ou a lojas com seus preços especiais. O jornalismo caracterizado pelos Jornais Estrella do Amazonas e o Catechista, é denominado de áulico, como já afirmamos. Para este tipo de jornalismo a notícia é o relato oficial. As suas fontes são quase exclusivamente as fontes governamentais. Pobre em informações é cheio de retórica em sua linguagem, laudatório. Portanto, o uso de ambos como fonte nos aproxima das falas e fontes oficiais presentes nestes jornais.

\section{O Caso do Padre Pardo Daniel Pedro Marques de Oliveira}

A despeito das discussões já suscitadas quanto ao caráter brando da escravidão na Província do Amazonas, a precocidade com que os escravos foram manumitidos ou mesmo em relação ao impacto rarefeito, economicamente falando da mão de obra escrava de origem negra, a história social tenta desnudar a trajetória de indivíduos que, longe da visão passiva, são agentes e atores históricos que merecem a reconstrução de suas experiências e estratégias de sobrevivência e ascensão social.

O vigário pardo Daniel Pedro Marques de Oliveira, nascido na Província do Pará, mãe mulata, escrava de seu pai, nos conduz a um labirinto de estratégias tanto de mobilidade social de indivíduos "não brancos", no Amazonas do século XIX, como a

Revista Eletrônica da ANPHLAC, ISSN 1679-1061, n. 16, p. 85 - 114, Jan./Jul. 2014. http://revista.anphlac.org.br 
tentativa da própria sociedade em "racializar" tais indivíduos e construir uma ideologia em torno do trabalho, atrelado às teorias racistas e da noção de civilidade próprias dos oitocentos.

Durante o século XIX as teorias raciais ganham espaço no meio científico e a argumentação biologizante permite naturalizar desigualdades sociais. Hebe Mattos afirma que o conceito de raça é uma construção deste período, o que permite a "racialização" da justificativa da escravidão americana. Para a autora:

A noção de raça é assim uma construção social do século XIX, estreitamente ligada, no continente americano, às contradições entre os direitos civis e políticos inerentes à cidadania estabelecida pelos novos estados liberais e o longo processo de abolição do cativeiro. (MATTOS, 2004, p. 12)

Cria-se, de acordo com a autora, a visão de que alguns grupos eram racialmente inferiores e a partir daí justifica-se a restrição destes grupos aos direitos civis e a cidadania. A legitimação da escravidão moderna não se faz em bases raciais o que não implica considerar que estigmas e distinções apoiados na ascendência deixassem de existir nas sociedades do antigo regime e principalmente no Império Português.

Hebe Mattos afirma que o estatuto da pureza de sangue em Portugal limitava o acesso a cargos públicos, eclesiásticos e títulos honoríficos aos cristãos velhos o que excluíam descendentes de mouros e judeus, a partir das Ordenações Afonsinas (144647). Com as chamadas Ordenações Filipinas (1603) seriam acrescentadas à lista de exclusões os negros e mulatos. Apenas em 1776 com o Marquês de Pombal seriam revogadas as restrições para judeus, mouros e indígenas ao acesso a determinados privilégios e honras exclusivos dos súditos do Império. Em relação aos descendentes de africanos, só seriam rompidas tais restrições com o estabelecimento da Constituição de 1824, que definiu pela primeira vez os direitos de cidadania no Brasil (MATTOS, 2004, p. 12).

O mencionado estatuto de pureza de sangue possuía uma base religiosa, porém construía um estigma baseado na ascendência "proto-racial" que era usada não para justificar a escravidão, mas para garantir os privilégios e honras da nobreza, formada pelos cristãos velhos e livres. Para a autora, o Império Português entendia como

Revista Eletrônica da ANPHLAC, ISSN 1679-1061, n. 16, p. 85 - 114, Jan./Jul. 2014.

http://revista.anphlac.org.br 
desígnio divino as hierarquias sociais, sendo a pureza de sangue um dos elementos que garantiam o lugar social dos cristãos velhos no Império. Fazer parte do Império era tornar-se católico através do batismo e, nesse sentido, a escravidão dos bárbaros era aceita como um dos caminhos para servir ao rei e a verdadeira fé. Tal concepção validava tanto a escravidão africana quanto a indígena, para esses últimos legalizada a partir das guerras justas (MATTOS, 2004, p. 14).

Há uma forte associação entre a diáspora africana e a escravidão americana, fato que segundo Hebe Mattos obscureceu o "caráter não racial da origem da instituição". A importância da escravidão indígena para a América Portuguesa até o século XVIII, associa-se ao contínuo crescimento de uma população livre e de ascendência africana no mesmo período. É sobre essa população que recai o que Mattos denomina de "mancha de sangue" (2004, p. 15).

A Constituição de 1824 marca de acordo com a autora, o complexo jogo classificatório e identitário no Brasil, pois fruto da decisão de emancipação política, faz surgir o "brasileiro", fruto do contraste de dois estrangeiros cotidianos: o português e o africano (MATTOS, 2004, p. 18).

A Constituição de 1824 naturalizou todos os nascidos em Portugal e que permaneceram no Brasil após a independência, de maneira que, como atesta Hebe Mattos (2004), durante as primeiras décadas do Primeiro Reinado, brasileiros e portugueses foram identidades intercambiáveis e carregadas de conteúdos políticos.

Já nos primeiros anos do período regencial ocorre a proliferação de pasquins exaltados que lutavam pela igualdade de direitos entre os cidadãos, independente da cor, como garantia a constituição. Os nomes dos jornais eram sugestivos: O Homem de Cor, O Brasileiro Pardo, O Mulato, O Cabrito (MATTOS, 2004, p. 21).

A manutenção da escravidão e a restrição aos direitos civis e políticos aos libertos tornava-se uma questão crucial na vida de amplas camadas de populações urbanas e rurais do período. A autora afirma que apesar da igualdade de direitos civis entre os brasileiros, os "não-brancos" continuavam a ter mesmo direitos básicos negados, como o direito de ir e vir que dependia do reconhecimento costumeiro da condição de liberdade do indivíduo. Se confundido com cativo ou liberto o indivíduo estaria sob suspeita de ser escravo fugido, sujeito então à perseguição e todo o aparato

Revista Eletrônica da ANPHLAC, ISSN 1679-1061, n. 16, p. 85 - 114, Jan./Jul. 2014. http://revista.anphlac.org.br 
arbitrário usado na captura dos fugitivos, caso não apresentasse sua carta de alforria. (MATTOS, 2004, p. 21).

A marca da discriminação herdada do Império Português, para Hebe Mattos, residia no fato de que a igualdade entre os cidadãos reivindicada pelas populações livres "de cor" implicava no "silenciamento sobre sua própria cor". Este silenciamento de acordo com a autora se fazia de maneira politizada. A simples alusão da categoria cor nas primeiras experiências de recenseamento no Império gerou protestos generalizados (2004, p. 21).

Diversos trabalhos se debruçam a respeito do debate racial ocorrido no Brasil no final do século XIX e primeiras décadas do século $\mathrm{XX}^{5}$. A principal característica de tais obras consiste no fato de que elas analisam o debate racial do período enfocando tanto os problemas da possibilidade da construção de uma nação civilizada nos trópicos quanto o fato do Brasil ser constituído em sua grande maioria por negros e mestiços (COSTA, 2001).

Para Kabengele Munanga (1999), ao se analisar o discurso do que o autor classifica como "elite intelectual brasileira", no final do século XIX e primeiras décadas do XX, observa-se a construção de um modelo racista "universalista" que nega absolutamente as diferenças. Surge nesse sentido um ideal implícito de homogeneização que deveria se realizar pela miscigenação tanto física quanto cultural.

O autor esclarece seu ponto de vista, ressaltando sua visão sob a mestiçagem: "Por isso, a mestiçagem como etapa transitória no processo de branqueamento constitui peça central da ideologia racial brasileira (....)” (MUNANGA, 1999, p. 09)

Munanga afirma que o modelo racista defendido pela elite brasileira é diferente da ideologia racial praticada nos Estados Unidos, pois neste país procurou-se assegurar a supremacia racial branca a partir de um sistema segregacionista. O racismo universalista não se opôs ao processo de mestiçagem e também, pelo menos em teoria, não desenvolveu uma mixofobia. A miscigenação oferecia um caminho para afastar as diferenças das raças e principalmente afastar a influência da cultura negra na sociedade (1999, p. 13).

\footnotetext{
${ }^{5}$ Referimos-nos principalmente às obras SCHWARCZ, Lilia. O espetáculo das raças. São Paulo, Companhia das Letras, 1995 e MUNANGA, Kabengele. Rediscutindo a mestiçagem no Brasil. Identidade nacional versus identidade negra.Petrópolis, Vozes, 1999.
}

Revista Eletrônica da ANPHLAC, ISSN 1679-1061, n. 16, p. 85 - 114, Jan./Jul. 2014. 
Munanga afirma que a elite brasileira constrói o debate em torno da identidade nacional a partir de um modelo dominante de racismo:

A elite "pensante" do Brasil foi muito coerente com a ideologia dominante do racismo vigente, ao encaminhar o debate em torno da identidade nacional, cujo elemento de mestiçagem oferecia teoricamente o caminho. Se a unidade racial procurada não foi alcançada, como demonstra hoje a diversidade cromática, essa elite, não deixa de recuperar essa unidade perdida, recorrendo novamente à mestiçagem e ao sincretismo cultural. De fato, o que está por trás da expressão popularmente tantas vezes repetida: "no Brasil todo mundo é mestiço", senão a busca da unidade nacional racial e cultural? (...). (1999, p. 13)

No Brasil, ainda de acordo com o autor, a classificação racial do mestiço está ligada mais às marcas e cor da pele do que na origem e no sangue como em outros países (Estados Unidos e África do Sul, por exemplo). Afirma ainda que dependendo do grau de miscigenação, o mestiço brasileiro pode "atravessar a linha ou fronteira de cor" e se reclassificar na categoria cromática como "branco". Raramente conforme assinala o autor, ocorre um "rebaixamento" uma classificação como "negro", salvo raras exceções.

Daniel Pedro Marques de Oliveira, filho natural da mulata Anna Joaquina, escrava de seu próprio pai, José da Costa Albernaz. Nasceu na fazenda de propriedade de seu genitor, em 28 de março de 1828 na Província do Grão-Pará, na fazenda Pernambuco. Foi batizado no dia 10 de maio de 1830, numa capela de nome Nossa Senhora da Estrela, tendo como padrinhos Policarpo Lucas Monteiro, casado e, por madrinha, Josefa Maria da Conceição, solteira. Seus padrinhos eram cidadãos livres, brancos, possivelmente pessoas próximas a seu pai (JORNAL O CATECHISTA, 1863).

Padre Daniel, homem pardo, cuja trajetória se pautou pela proteção a fugitivos do cativeiro ${ }^{6}$, pela denúncia da violência dos escravocratas da Província e pelo incentivo à emancipação, uniu sua atividade eclesiástica, ao exercício do magistério e posteriormente ampliou sua atuação como deputado da Província do Amazonas, cargos exercidos ao longo das décadas de 1860 e 1870.

\footnotetext{
${ }^{6}$ Em março de 1860, o jornal Estrella do Amazonas noticiou a captura de sete escravos fugidos que durante quase dez anos viveram em Silves sob a proteção de autoridades públicas, entre delegados e vereadores. O vigário Daniel, em defesa das autoridades silvenses, acusou o Chefe de Polícia de "perseguição política" e logo foi também acusado de cumplicidade no açoitamento dos fugitivos.

Revista Eletrônica da ANPHLAC, ISSN 1679-1061, n. 16, p. 85 - 114, Jan./Jul. 2014.

http://revista.anphlac.org.br
} 
A trajetória do padre Daniel desde sua colação como vigário em Silves até o início de sua carreira como político é marcada por polêmicas, disputas políticas e uma ferrenha oposição de seus adversários que se utilizaram de argumentos raciais para desqualificar sua figura pública. $\mathrm{O}$ apogeu deste processo, possivelmente encontra-se na eleição para deputado provincial em 1863, quando sua origem e cor (se era escravo ou liberto, passando também pelas gradações de cores, ora apontado nos jornais como pardo ora como negro) sendo o motivo utilizado por seus adversários políticos para a anulação da eleição daquele ano.

Sua trajetória política esteve ligada à sua atuação como vigário colado de Silves e também com o exercício do magistério, fato que possibilitou a construção de uma rede de relações sociais que se ampliou nas décadas de 1860 e 1870 quando padre Daniel foi deputado Provincial em 1860, assumindo funções de relator da comissão de instrução pública e relator da comissão eclesiástica; entre os anos de 1864 e 1865 . Na década de 1860 assume funções de deputado durante mandato de presidentes vinculados à "Liga Progressista". Já na década de 1870 sempre assume mandatos como deputado onde o presidente da Província era do Partido Conservador. Em 1869 foi novamente relator da comissão de instrução pública e em 1870, assume mandato de deputado entre 1872 a 1879, consecutivamente sendo em 1876 e 1877 vice-presidente da Assembleia provincial, fato que demonstra a fortíssima articulação política em torno do padre Daniel Pedro Marques de Oliveira (ANAIS DA ASSEMBLEIA LEGISLATIVA DO ESTADO DO AMAZONAS).

De acordo com a ficha eclesiástica do padre Daniel Pedro Marques de Oliveira, este foi ordenado diácono em 25 de julho de 1850, por dom José Afonso, sendo vigário em Silves em 1871. Ainda segundo essa fonte, padre Daniel teria sido suspenso de suas ordens por 30 dias no ano de 1863, por ter se ausentado de sua freguesia sem licença competente, punição imposta por dom Macedo Costa, em 06 de fevereiro de 1863. Quanto à data de falecimento, de acordo com o documento, ocorreu em 1881. O documento apresenta dados como data e local do nascimento, nome do pai e mãe, local onde fez estudos primários e quando entrou no seminário. Provavelmente preenchida na data do falecimento do padre a fonte encontra-se praticamente em branco, diferentemente do que observamos com outros sacerdotes que possuem mais

Revista Eletrônica da ANPHLAC, ISSN 1679-1061, n. 16, p. 85 - 114, Jan./Jul. 2014.

http://revista.anphlac.org.br 
informações a respeito de suas trajetórias dentro do clero (Arquivos da Cúria Metropolitana de Manaus).

Em cartas da sua atuação sacerdotal encontramos documentos que atestam quais os cargos ocupados pelo padre Daniel durante o período em que foi vigário colado de Silves: "Daniel Pedro Marques d'Oliveira, Presbítero Secular, Delegado da Companhia Luso-Brazileira, Deputado à Assembleia Legislativa Provincial do Amazonas, e Vigário Colado na Paróquia de Silves [...]" (Arquivos da Cúria Metropolitana de Manaus).

$\mathrm{O}$ fato de ser do clero secular possivelmente estaria ligado a restrições impostas pela igreja aos descendentes de escravos que se inseriam no clero. De acordo com Oliveira (2008), os padres pardos ou mulatos deveriam solicitar antes de sua ordenação a autorização para ingressar no clero, declarando-se 'dispensados do defeito da cor' para poderem ser aceitos como tal.

Em Falla do Presidente do Amazonas de 1857 aparece o Mapa da Divisão Eclesiástica da Província. Nele, padre Daniel Pedro Marques de Oliveira é apresentado a Freguesia de Sant'Anna de Silves em 18 de julho de 1854 e a data de sua colação em 24 de agosto de 1854. No mesmo documento aparece a provisão do padre Daniel em 29 de outubro de 1855, em Silves, como professor interino de primeiras letras para 41 alunos do sexo masculino. (FALLA DO PRESIDENTE DA PROVÍNCIA DO AMAZONAS, 1857).

Na Exposição do Presidente da Província do Amazonas em 1858, a respeito do Seminário Episcopal de Manaus, que de acordo com o documento era filial do seminário de Belém, além de breve relato das dificuldades da criação do seminário, ressalta a participação de padre Daniel Marques de Oliveira como professor de gramática latina entre 10 de dezembro de 1858 e abril de 1858 (FALLA DO PRESIDENTE DA PROVÍNCIA DO AMAZONAS, 1857).

As funções sacerdotais de padre Daniel de Oliveira são ampliadas pelo exercício precoce do magistério, fato corroborado pelas informações citadas acima e também por outros documentos, nos quais aparece a figura do religioso nos quadros do funcionalismo como professor de primeiras letras. Em 02 de agosto de 1865 foi nomeado como serventuário efetivo com 106 alunos matriculados na cadeira sob sua

Revista Eletrônica da ANPHLAC, ISSN 1679-1061, n. 16, p. 85 - 114, Jan./Jul. 2014. http://revista.anphlac.org.br 
responsabilidade em Silves (FALLA DO PRESIDENTE DA PROVÍNCIA DO AMAZONAS, 1871).

$\mathrm{Na}$ exposição de 1874, que trata do quadro pessoal empregado na instrução pública da província aparece a descrição da atividade do Padre Daniel de Oliveira como professor em Silves nomeado em 02 de agosto de 1865 e aposentado em 20 de maio de 1873 (EXPOSIÇÃO DO PRESIDENTE DA PROVÍNCIA DO AMAZONAS, 1874).

Daniel de Oliveira, como outros padres pardos, possivelmente encontrou na ordenação sacerdotal a possibilidade de mobilidade social e a busca de privilégios que o afastassem das experiências do cativeiro. A estratégia adotada de encontrar nas ordens religiosas o acesso a oportunidades de que se valeu o padre pardo surtiu o efeito desejado na medida em que durante as décadas de 1860 e 1870 exerceu atividades de destaque como professor e deputado provincial $^{7}$.

Em sua atuação como deputado Provincial, padre Daniel de Oliveira denunciou ao presidente da Província em janeiro de 1874 que a mulata Benedita, estava sendo mantida irregularmente como cativa na vila de Silves por João Roiz Terço. Benedita é descrita pelo padre como "mulata" e "infeliz brasileira", portanto, aos olhos do sacerdote, o mesmo estava defendendo os direitos de uma cidadã. $\mathrm{O}$ texto faz alusão à carta de alforria da mulata, conforme veremos a seguir.

Padre Daniel, escreve denunciando junto às autoridades a condição em que se encontrava a mulata Benedita, segundo o clérigo, liberta em agosto de 1873. Descreve a situação irregular perante a lei, como zombaria e afirma que a mulata sofria tratamento bárbaro pelo seu algoz, caracterizado como homem violento e de péssimos precedentes:

(...) Pela inclusa carta de alforria, verá V.Exa. que a mulata Benedita é liberta desde 30 de Agosto de 1873. Sendo, porém, público e notório nesta vila, que essa infeliz continua a viver até esta data debaixo de um cruel cativeiro, sofrendo que diariamente os mais bárbaros tratamentos de João Roiz Terço, homem de gênio violento e de péssimos precedentes; que, por vezes, tem aqui zombado da lei e da autoridade, recorro à Vossa Excelência, rogando-lhe se sirva garantir a

\footnotetext{
${ }^{7}$ Citemos alguns exemplos de autores que abordam a questão de padres de origem escrava e as estratégias de mobilidade social cf. NEVES, Guilherme Pereira das. E Receberá Mercê: a Mesa da Consciência e Ordens e clero secular no Brasil 1808-1828. Rio de Janeiro: Arquivo Nacional, 1997. OLIVEIRA, Anderson José Machado de. Devoção Negra: santos pretos e catequese no Brasil colonial. Rio de Janeiro: Quartet/Faperj, 2008. VILLALTA, Luiz Carlos. A Igreja, a sociedade e o clero. In: LAGE, Maria Efigênia de Resende e VILlALTA, Luiz Carlos (orgs). História de Minas Gerias - As Minas Setecentistas 2. Belo Horizonte: Autêntica/Companhia do Tempo, 2007.
}

Revista Eletrônica da ANPHLAC, ISSN 1679-1061, n. 16, p. 85 - 114, Jan./Jul. 2014.

http://revista.anphlac.org.br 
liberdade dessa infeliz brasileira. Levando este fato ao conhecimento de Vossa Excelência creio que cumpro um dever inerente ao meu ministério, qual o de proteger dos infelizes e desvalidos, máxime os que estão confiados à minha jurisdição espiritual. (...) (ARQUIVO PÚBLICO DO ESTADO DO AMAZONAS).

Como podemos observar no texto acima, padre Daniel ao denunciar as sevícias cometidas contra a liberta Benedita estava apenas "cumprindo um dever inerente ao seu ministério". "Proteger os desvalidos e os infelizes." Este era o papel do clérigo? Ou sua “jurisdição espiritual” se confundia com sua atuação política?

Não seria a primeira nem a última vez que padre Daniel estaria envolvido em questões polêmicas. Pardo, o que para a época vinculava sua origem negra a sua condição de homem livre, acusado de diversos crimes, teve forte presença no cenário político da vila de Silves, sendo virulentamente perseguido pelos seus adversários políticos, (em via de regra autoridades locais, denunciadas por arbitrariedades) por conta de sua condição (liberto) e sua cor (pardo).

O vigário Daniel de Oliveira utilizava-se de sua certidão para se defender de seus acusadores. Desejava pelas páginas dos jornais provar que não era escravo, muito menos liberto. Para tanto se utiliza de sua certidão tentando constatar sua condição de livre. Argumenta demonstrando erudição e profundo conhecimento não apenas nas escrituras sagradas, mas também das leis do Império. Tal argúcia possibilitou ao padre uma atuação política que incomodou durante muitos anos as autoridades e a posição inusitada de um pardo que se consolidou como liderança política na Província. Afirmava que havia herdado de seu pai desde sua infância a liberdade, se declarava cidadão livre, fato que lhe garantiria a participação das eleições, algo que estava sendo negado a ele no ano de 1863. Utilizou-se de seus conhecimentos, por ser sacerdote, recorrendo às sagradas escrituras defendendo sua posição de livre: "O novo testamento, diz-nos o Rvm, proclama todos os homens livres, logo sou livre”! Busca na lei a justificativa para sua liberdade, é notadamente alguém diferenciado, capaz de argumentar contra seus adversários, que conhece seus direitos e as brechas na lei que garantiam sua atuação política, independente do seu passado, das heranças do cativeiro, ou de sua cor e de sua mãe, escrava mulata, portanto mestiça, ter sido propriedade do seu pai.

Revista Eletrônica da ANPHLAC, ISSN 1679-1061, n. 16, p. 85 - 114, Jan./Jul. 2014. http://revista.anphlac.org.br 
Em 1870, padre Daniel de Oliveira, terminou a eleição provincial empatado em número de votos com Thomaz Luiz Simpson (31 no total) e quase assume o posto de deputado após a anulação da eleição de José Bernardo Michilles. Só não assumiu porque o substituto de Michilles foi escolhido por sorteio (ANAIS DA ASSEMBLEIA LEGISLATIVA DO AMAZONAS DE 1870-1871).

Em março de 1872 após mais de uma década de acirradas lutas, o sacerdote chegou ao então posto de deputado da Assembleia Provincial (ANAIS DA ASSEMBLEIA LEGISLATIVA DO AMAZONAS DE 1870-1871). Isso sem falarmos da eleição anulada por sua participação da mesa eleitoral em 1863. Estamos, portanto, diante de uma personagem que durante quase uma década esteve no centro das disputas políticas do período provincial no Amazonas e carregou consigo o peso da condição de liberto, além das marcas de sua origem: pardo.

Em fevereiro de 1859 o Jornal Estrella do Amazonas noticiava a prisão do sacerdote por agressão a uma autoridade:

No dia 15 - De ordem do sr. Dr. Chefe de policia o vigário da Villa de Silves, Daniel Pedro Marques de Oliveira e o alferes da guarda nacional, Fidelles Alves da Costa, pronunciados pelo espancamento do ex subdelegado da mesma vila, Olimpio da Costa dos Santos por perjúrio (JORNAL ESTRELLA DO AMAZONAS 9 DE FEVEREIRO DE 1859)

Tal fato foi utilizado inclusive para o impedimento de sua participação nas eleições provinciais. Foi solicitado o voto em separado do sacerdote, por conta do processo em que estava envolvido motivado pela suposta agressão ao subdelegado de Silves. A mesa eleitoral recebera um requerimento solicitando o voto em separado do padre sob alegação de que estava sendo processado, o que suspenderia seus direitos políticos. Tendo sido absolvido das acusações:

A QUINZENA. - Manáos 09 de Janeiro (...) Domingo procedeu-se a eleição dos 8 membros e 4 suplentes da Assembleia Legislativa Provincial, que devo dar o circulo d'esta Capital, saindo eleitos os Deputados os Snres. Custodio Pires Garcia, Manoel Rodrigues Checks Nina, Vicente Alves da Silva, Dr. Jose Antonio de Freitas Junior, Padre Daniel Pedro Marques d'Oliveira, Joaquim Firmino Xavier, José de Carvalho Serzedello, e Francisco Antonio Monteiro Tapajós, que obtiveram maioria de votos na respectiva eleição; e Suplentes os

Revista Eletrônica da ANPHLAC, ISSN 1679-1061, n. 16, p. 85 - 114, Jan./Jul. 2014.

http://revista.anphlac.org.br 
Sres. Padre Manoel Lucupertino Salgado, Francisco de Paula Bello, e Manoel da Silva Ramos. A eleição correu calma e sem a menor intervenção da autoridade, dando-se apenas uma pequena irregularidade. Um dos Eleitores requereu em termos que o voto do Eleitor Padre Daniel fosse tomado em separado, visto como está ele sujeito aos efeitos de uma pronúncia em causa crime, e por tanto suspenso dos direitos políticos. Este requerimento porem, que tinha por fim arredar da eleição toda e qualquer ilegalidade e no qual devia votar todo o Colégio Eleitoral, foi peremptoriamente decidido pela Mesa, que o dito Eleitor votasse englobadamente com os outros (JORNAL ESTRELLA DO AMAZONAS 11 DE JANEIRO DE 1860).

De acordo com Pozza Neto (2011), entre as décadas de 1850 e 1870 cresceu o movimento emancipacionista tanto no Brasil quanto na Província do Amazonas. O padre Daniel de Oliveira parece ter papel de destaque no cenário político da Província por se articular contra os interesses escravocratas inclusive sendo acusado de açoitar escravos em fuga ${ }^{8}$.

Em 21 de março de 1860 o jornal Estrella do Amazonas noticiou fato curioso a respeito do acoitamento de oito escravos na vila de Silves. De acordo com a notícia autoridades daquela localidade estavam envolvidos no caso:

Denunciados como escravos 8 indivíduos, que na vila de Silves acoutados escarneciam da lei e zombavam de direito de propriedade serviam até cargos públicos; um de porteiro da Câmara Municipal e outro de cabo de trabalhadores (JORNAL ESTRELLA DO AMAZONAS 21 DE MARÇO DE 1860).

Interessante é que os escravos acoitados serviam como funcionários públicos na localidade, evidentemente com a conivência das autoridades locais:

O subdelegado e o comandante de trabalhadores, e o presidente da câmara são indigitados como protetores desses escravos, em consequência do que foram imediatamente demitidos os primeiros, a bem do serviço publico, e consta que o dr. Chefe de Polícia do Pará para averiguar o fato do acoitamento (JORNAL ESTRELLA DO AMAZONAS 21 DE MARÇO DE 1860).

\footnotetext{
${ }^{8}$ Dos dados coletados a respeito das alforrias na Província do Amazonas o autor afirma que o número de concessão de alforrias se concentra particularmente na década de 1870. (2011, p. 80) CF. NETO, Provino Pozza. Alforrias escravas na Província do Amazonas. In: O fim do silêncio: presença negra na Amazônia. Belém: Editora açaí, 2011.
}

Revista Eletrônica da ANPHLAC, ISSN 1679-1061, n. 16, p. 85 - 114, Jan./Jul. 2014.

http://revista.anphlac.org.br 
Foram de acordo com o noticiado no jornal capturados na vila de Silves sete dos oito escravos fugidos, dentre eles uma escrava parda de nome Ignez com seus cinco filhos, além do cabo de trabalhadores que conseguiu evadir-se. Eram em conformidade com a nota, escravos de um proprietário paraense de nome Amanajás e o acoitamento gerou a destituição das autoridades envolvidas no fato.

Para os padrões da época, o religioso era considerado pardo, na medida em que, segundo suas alegações, havia sido liberto na pia batismal. Temos acesso à fala do padre Daniel de Oliveira através de um texto do jornal $O$ Catechista, que buscava desconstruir seus argumentos; o texto responde ao artigo presente no jornal Estrella do Amazonas, escrito pelo religioso:

O novo testamento, diz-nos o Rvm, proclama todos os homens livres, "logo sou livre"!. He verdade quanto ao que diz o Evangelho; mas esta verdade, e a consequência que tira estão em flagrante contradição com os factos no Brasil nem todos são livres e prova está para si, mais que patente pois que nos confessa no seu granzel que sua mãe era escrava de José da Costa Albernarz, nos seguintes arrancos d'uma confissão pungente: meu prezadíssimo pai único que, na terra PODE chamar-se senhor de minha idolatrada mãe ...Logo a citação nada vem ao caso (...); pois que apesar do Novo Testamento, proclamar todos os homens livres, a mãe do Rvm, Sr. Daniel era escrava (JORNAL O CATECHISTA, 12 DE JANEIRO DE 1863).

Talvez por esta razão tenha despertado tanto o ódio por parte de seus adversários que tentaram desqualificar seus discursos e dimensionar de maneira negativa suas ações políticas. As querelas presentes nas páginas dos jornais ultrapassam as disputas entre interesses políticos diferenciados, ganham conotação de ódio racial e preconceito contra a condição e a cor do referido padre. O uso dos jornais como forma de externar posicionamentos políticos de distintos grupos nos propicia acompanhar de maneira indireta ao menos, as querelas entre o padre e as autoridades locais de Silves.

Ao buscar atacá-lo politicamente, as autoridades veiculavam pelos jornais, acusações e impropérios que deixam transparecer de que maneira a sociedade da época via os libertos, os não brancos, ou seja, as experiências do cativeiro marcavam profundamente uma sociedade rigidamente estratificada e hierarquizada onde a cor se configurava em um dos aspectos discriminatórios a estes grupos.

Revista Eletrônica da ANPHLAC, ISSN 1679-1061, n. 16, p. 85 - 114, Jan./Jul. 2014. http://revista.anphlac.org.br 
A participação política do padre Daniel demonstra a existência de uma prática política maleável, na medida em que as leis da época ao restringirem a participação do liberto impõe aos indivíduos ligados à experiência do cativeiro a posição de indivíduos sem direito à participação política efetiva, o que num primeiro momento não inviabilizou a atuação do padre.

Em 1863 o padre estaria no centro das disputas políticas da província do Amazonas. As eleições foram anuladas por conta da mesa eleitoral ter sido presidida pelo sacerdote, fato proibido pelas leis imperiais que restringia os direitos dos libertos apenas de exercer o voto e não de serem candidatos. Sendo ele um ex-escravo não poderia ser candidato, muito menos exercer o comando da mesa eleitoral.

O jornal $O$ Catechista publicou o assento de batismo do padre em busca de comprovar sua condição de liberto, talvez mesmo de escravo. O objetivo era restringir seus direitos de participação política, por conta de sua origem:

(...) [Certidão] - Certifico que revendo o Livro décimo sétimo de assentos de batismo da freguesia da Sé nele a folha uma até o verso se acha o assento seguinte - Aos dez dias de Maio de 1830 anos, nesta cidade do Pará na câmara Eclesiástica me foi apresentada uma petição de José da Costa Albernaz, em seu seguimento uma certidão do Teor seguinte. - No dia vinte e oito de março de mil oitocentos e vinte oito nesta capela de Nossa Senhora da Estrella da fazenda de Pernambuco, batizei solenemente e pus os Santos Óleos ao inocente Daniel filho natural de Anna Joaquina, mulata ESCRAVA de José da Costa Albernaz, (...) (JORNAL O CATECHISTA, 05 DE DEZEMBRO DE 1863).

O articulista do jornal $O$ Catechista defende seu ponto de vista a respeito das alegações de que o padre era liberto ou mesmo escravo afirmando que:

Difícil é a situação do jornalista imparcial, quando forçado pelo dever discute um ato publico, e vê-se depois de frente para sustentar suas opiniões com uma questão pessoal e odiosa. Tal é nossa atual situação (JORNAL O CATECHISTA, 12 DE DEZEMBRO DE 1863).

A visão de imparcialidade tinha duplo objetivo: primeiro convencer o leitor da veracidade dos fatos narrados, segundo esconder a vinculação de interesses expostos nas colunas dos jornais da época.

Revista Eletrônica da ANPHLAC, ISSN 1679-1061, n. 16, p. 85 - 114, Jan./Jul. 2014. http://revista.anphlac.org.br 
Sidney Chaloub em Trabalho Lar e Botequim (1986) faz inclusive alusão à forma como as notícias eram produzidas no período. Referindo-se a Lima Barreto, afirma que em alguns casos era absolutamente corriqueiro entre os articulistas o uso da criatividade e a invenção dos fatos (maior floreio) principalmente nas chamadas das notícias.

No caso do Jornal $O$ Catechista, o articulista reitera sua posição em alegar que o padre Daniel oscilava entre a condição de liberto e escravo:

Sua Rvma. Porem, pela Estrella no. 795 de 2 do corrente, acusa-nos de libelista, o porque isto dissemos e tentando destruir nossa asseveração de seu estado liberto, cego, apaixonado e mostrando sua ignorância, confessa se sentia escravo! (JORNAL O CATECHISTA, 12 DE DEZEMBRO DE 1863)

A ideia da imparcialidade do jornalista, e, portanto a neutralidade da matéria publicada em si, defendia o ponto de vista do próprio jornal, na tentativa de convencer o leitor de que as eleições da província do Amazonas naquele ano de 1863 deveriam ser anuladas devido à condição do padre Daniel e logicamente por conta de sua cor (exescravo, pardo):

Em o no. 83, discutindo as nulidades insanáveis das eleições porque passamos à pouco, fomos levados a mostrar entre outras causas, o ter sido o colégio da capital presidido por um liberto. Esse liberto, que apontamos então é o sr. Padre Daniel Pedro Marques de Oliveira.

Padre Daniel ao tentar se defender das acusações que sofria (a tentativa de impedimento da sua participação nas eleições provinciais) usa também os jornais para responder as acusações de ser ainda escravo ou liberto. Citando trechos das ordenações Filipinas e citações do Novo Testamento alega ser cidadão livre:

A ordenação [Liv. 4 Tit. 92 pr. e Reper] nosso direito pátrio civil proclama que o filho que o homem solteiro peão houver de alguma escrava sua é livre e lhe sucede na herança: eu sucedi na herança de José da Costa Albernaz, senhor de minha mãe logo sou livre (JORNAL O CATECHISTA, 12 DE DEZEMBRO DE 1863).

Vejamos a partir da resposta do jornal $O$ Catechista a fala do sacerdote:

Revista Eletrônica da ANPHLAC, ISSN 1679-1061, n. 16, p. 85 - 114, Jan./Jul. 2014. http://revista.anphlac.org.br 
O Rvm. é escravo se não provar com documento que foi alforriado, ou não nos mostrar que o tribunal para o qual tentou ação de prescrição o considerou liberto. O Rvm. jamais pode ser livre na expressão da lei, na sua letra clara. Porquanto ficou provado (...) ter nascido de ventre escravo: e a lei diz claramente que só pode gozar de liberdade, se alcançar alforria. (...) O Rvm. o mais que pode subir na escala social é a camada dos LIBERTOS (JORNAL O CATECHISTA, 12 DE DEZEMBRO DE 1863).

Além da sua atuação como sacerdote, como já citamos, padre Daniel era um indivíduo com bastante instrução, na medida em que atuava também como educador em Silves. Podemos observar que sua atuação enquanto sacerdote e posteriormente sua vida política constituem a personalidade de um indivíduo que busca fugir das amarras sociais predeterminadas pela cor ou condição social.

A impossibilidade de subir na escala social, que se lhe foi imposta está presente no texto acima, matéria do Jornal $O$ Catechista, expõe a partir da fala do artigo a própria visão que se tinha a respeito dos grupos ligados aos escravos e ex-escravos, a condição intermediária destes, por sua origem. $\mathrm{O}$ escravo jamais seria um cidadão, seria no máximo liberto, por isso mesmo com restrições à sua cidadania.

Há na história do padre Daniel uma série de aspectos importantes que revelam a maneira como a questão racial é manejada nos debates jornalísticos e a forma como sua cor depunha contra seus discursos e dimensionava negativamente suas ações. Para seus "inimigos políticos" o padre seria para sempre um ex-escravo.

A possibilidade de considerarmos padre Daniel como liderança política é inegável, na medida em que os jornais nos fornecem pelo menos indiretamente indícios a respeito de suas ações de crítica às autoridades políticas vigentes e sua posição contrária à questão da escravidão. A busca incessante de sua liberdade política nos apontam possibilidades para a discussão da identidade do negro na sociedade amazonense, mesmo que a partir do prisma de um indivíduo e de sua atuação política marcante como o padre Daniel.

Em agosto de 1860 o jornal Estrella do Amazonas publicou nota assinada pelo então escrivão Manoel do Nascimento Figueira, acusando padre Daniel de querer ampliar sua atuação para além dos assuntos eclesiásticos. A nota do jornal é bem enfática ao retratar tanto a visão negativa a respeito da sua origem étnica (ataca a sua índole e faz alusão à cor da sua pele) quanto o ameaça diretamente a cadeia e açoite:

Revista Eletrônica da ANPHLAC, ISSN 1679-1061, n. 16, p. 85 - 114, Jan./Jul. 2014. http://revista.anphlac.org.br 
O padre mestre não se contenta com o campo de sua paróquia para fomentar a desordem, quer campo maior e achou que eu devia servirlhe de pasto a sua loquacidade. Enganou-se completamente por que estou disposto a não despor mais de minha dignidade para dar troço a semelhante besta, a menos que não tire a mascara e apareça a peito descoberto, por que quero mante-lo ainda uma vez na cadeia; ouviu padre mestre? Si esta lição, padre mestre, não vos serve ainda, então convencerás ao publico sensato, que só vergalho é que vos pode endireitar; mas qual! Preto quando não suja, tisna. (JORNAL ESTRELLA DO AMAZONAS, 25 DE AGOSTO DE 1860).

A ameaça fica evidenciada: só vergalho pode endireitar o padre. Logo depois preconceito toma conta das páginas do jornal: preto quando não suja, tisna! Aqui a presença das ofensas e ameaças evidencia que a luta virulenta e de oposição às ações políticas do sacerdote ultrapassam os posicionamentos políticos e caem no campo do preconceito de raça particularmente presente no século XIX: a inferioridade dos negros, e sua impossibilidade de alcançarem a civilização pelas experiências do cativeiro.

No mesmo mês e ano o jornal Estrella do Amazonas voltou a ameaçar o religioso e desfere contra sua figura uma série de graves acusações. Afirma ser o "evangelista do deboche e da prostituição".

Alude ao fato do padre lecionar para jovens acusando-o de aliciar suas alunas. Tal acusação não impediu o clérigo de solicitar junto às autoridades (e conseguir) a abertura de uma escola em Silves em novembro do mesmo ano. O jornal em sua parte oficial publicou nota da solicitação do padre para abertura de uma escola em novembro de 1863:

De Daniel Pedro Marques de Oliveira [Vigário Colado da Vila de Silves], pedindo permissão para abrir uma escola na freguesia de Silves, de gramática latina, Francesa, retorica, e Filosofia racional. Concedo a autorização requerida. Passe-se o competente título (JORNAL ESTRELLA DO AMAZONAS, 28 DE NOVEMBRO DE 1860).

Outra acusação feita no artigo do jornal é a de que padre Daniel teria, além de aliciar mulheres casadas e jovens inocentes (se aproveitando de sua condição de padre e professor) teria falsificado a carta de alforria de sua mãe para poder conseguir sua ordenação:

Revista Eletrônica da ANPHLAC, ISSN 1679-1061, n. 16, p. 85 - 114, Jan./Jul. 2014.

http://revista.anphlac.org.br 
O padre mestre de Silves é o evangelista do deboche e da prostituição, solicita intra e extra confissões as mulheres casadas, solteiras e donzelas, e como prova cita-se d. Inácia, as menores que por suas artimanhas estiveram depositadas em sua casa aos seus desejos, e as meninas que (coitadinhas!) iam a sua casa a título de aprenderem a ler beber o veneno da imoralidade (...) mandou chibatar e por em ferros um cidadão mais livre do que ele; conseguiu por suas astúcias do tabelião João Corrêa registrar no seu cartório uma carta de liberdade, da preta sua mãe por ocasião de ser preterido em sua ordenação em consequência de ex defectu liberdatis (...) (JORNAL ESTRELLA DO AMAZONAS, 22 DE AGOSTO DE 1860).

A série de notas do jornal Estrella do Amazonas faz menção ainda a furto e imagens e relíquias da igreja (atribuídas ao padre) e processos contra o mesmo?

(...) furtou $200 \$$ rs. dos cofres dos pontificais, quando encarregado dessa repartição na sé do Pará; furtou segundo a participação do juiz de paz as joias das Imagens das igrejas de Silves e Jatapú finalmente, tem sido submetido a 3 ou 4 processos e prezo pelas suas altas virtudes. Tudo isto é meramente hipotético, mas que o respeitável público, caprichoso como é, pode converter, querendo, em verdades matemáticas (JORNAL ESTRELLA DO AMAZONAS, 22 DE AGOSTO DE 1860).

Notemos a partir da citação acima que o próprio texto do jornal afirma que todas estas acusações são meramente hipotéticas, mas mesmo assim presume-se pela "verdade matemática".

Na crônica A Quinzena o padre é retratado como pescador de águas turvas que tem o interesse de transtornar a sociedade:

Todo corre placidamente; apenas um ou outro pescador d'aguas turvas trabalha com afã por transtornar este estado lisonjeiro.

Mas temos fé nos brios dos amazonenses que serão em tempo repelidos, como merecem, e conhecerão que o caboclo do Amazonas tem nas suas flechas e frutos silvestres todos os elementos para resistirem a imposições de intrusos, que não têm o menor direito de intervir na direção de sua sorte. (...) (JORNAL ESTRELLA DO AMAZONAS, 24 DE AGOSTO DE 1860).

\footnotetext{
${ }^{9}$ O Jornal Estrella do Amazonas de 24 de março de 1860 solicita o envio da copia do processo que absolvia o padre Daniel de uma destas acusações: "Ao juiz de direito interino da comarca da capital, determinando-lhe que envie com a possível brevidade copia autêntica da sentença proferida contra o vigário da vila de Silves Daniel Pedro Marques de Oliveira, no processo que foi submetido ao júri na $2^{\mathrm{a}}$ sessão do ano passado, bem como a da absolvição em consequência da decisão do júri”. O mesmo jornal em agosto ignora absolvição do sacerdote em uma das acusações.
}

Revista Eletrônica da ANPHLAC, ISSN 1679-1061, n. 16, p. 85 - 114, Jan./Jul. 2014.

http://revista.anphlac.org.br 
Evidencia-se a partir do termo pescador (em alusão a função sacerdotal?) de águas turvas que o objetivo e mais uma vez questionar a intervenção do Padre em assuntos diversos na comunidade de Silves. Turvas, seria alusão ao seu caráter? A sua cor da pele? Ou ambos? Importante frisar que o texto encerra-se afirmando que o padre não tem direito de interferir na sorte do "caboclo do Amazonas".

Notemos a presença da visão do caboclo à sua condição e herança da cultura indígena vista como oposta à civilização: a cultura material (portar flechas e comer frutos silvestres) aludida no texto serve de exemplo também de como se apresentava o preconceito também contra os indígenas e sua influência na sociedade.

As imposições de um intruso referem-se ao fato do padre Daniel ser de fora da Província, nascido como vimos em Belém no final da década de 1820. O artigo acima citado demonstra preocupação em relação à atuação política do padre, que se utilizava, segundo esta visão, de sua posição para intervir na vida da sociedade amazonense. $O$ sacerdote era caracterizado negativamente e a forma como era definido sempre aludiam ao fato de ser liberto, escravo, e ou preto, de acordo com o teor dos textos.

No jornal Estrella do Amazonas de 20 de junho de 1860 aparece tanto a preocupação quanto ao peso político do padre Daniel, comparada a um "dedo de gigante", quanto a sua origem racial: cara branca e língua preta. No texto evidencia-se a ideia de que o padre utiliza-se de ardis para mascarar sua condição de liberto e procurar utilizando-se de sua posição como padre, gozar os privilégios de cidadão livre:

Fazemos este pedido não por que não conheçamos pelo dedo o gigante, que (...) tem até hoje, por uma tolerância imperdoável, gozado dos foros de cidadão livre; mas por que queremos ter o prazer de ver a cara branca do - Silviense - e língua preta (JORNAL ESTRELLA DO AMAZONAS, 20 DE JUNHO DE 1860).

No mesmo jornal a ideia de que o padre esconde sua origem e atua de maneira criminosa fica evidente e mais uma vez se alude à condição do padre sempre presente de maneira dúbia: escravo ou liberto? Porém nunca como cidadão livre:

Rogo-lhe que tire a máscara, saia dos bastidores e acuse-me a peito descoberto sob pena de ser tido por criminoso escravo ou liberto, que teme a ação da justiça, a que chama perseguição - escravidão - e Revista Eletrônica da ANPHLAC, ISSN 1679-1061, n. 16, p. 85 - 114, Jan./Jul. 2014. http://revista.anphlac.org.br 
prepotência o que não podendo defender os seus parceiros escravos, que naquela vila gozavam dos foros de cidadãos (JORNAL ESTRELLA DO AMAZONAS, 20 DE JUNHO DE 1860).

A acusação que paira neste trecho é a de que o padre Daniel configurava-se como acoitador de escravos. No texto os escravos são seus "parceiros". Alude-se ao fato de que o padre tentava atuar politicamente contra a escravidão para defender os escravos, utilizando-se até do subterfúgio de acoitar os mesmos. Compara-se o padre com os escravos fugitivos: estes gozavam de foros de cidadãos, pois escondiam sua origem e condição.

Em diversas passagens dos jornais os artigos relembravam a condição de preta e escrava da mãe do padre Daniel, mesmo que nos documentos oficiais ela fosse descrita como mulata. Aqui não importa a cor da pele e sim a vinculação da raça biologicamente falando. A própria condição do padre era assinalada de maneira dúbia, ora liberto, ora escravo, pardo, preto.

Como afirmamos anteriormente, a concepção de raça construída a partir da concepção biológica faz parte do ideário do século XIX.

Aqui recorremos à fala de Serge Gruzinski, a respeito da mestiçagem quando este afirma que:

\begin{abstract}
As relações entre vencedores e vencidos também assumiram forma de mestiçagens, alterando os limites que as novas autoridades procuravam manter entre as duas populações. Desde os primeiros tempos, a mestiçagem biológica, isto é, a mistura de corpos - quase sempre acompanhada pela mestiçagem de práticas e crenças introduziu um novo elemento perturbador (...) Estupros, concubinagens, mais raramente casamentos, geraram uma população de tipo novo, de estatuto indefinido - os mestiços, a respeito dos quais não se sabia muito bem se deveriam ser integrados ao universo espanhol ou às comunidades indígenas (...) Por todas essas razões, índios negros e espanhóis tiveram de inventar, dia após dia, modos de convívio ou, especialmente os primeiros, soluções de sobrevivência (2001, p. 78).
\end{abstract}

Ao nos debruçarmos sobre a história do padre Daniel, há evidentemente mais questionamentos do que respostas ao reconstruirmos sua trajetória. O padre, sendo pardo, vinculado à igreja, indivíduo culto e atuante politicamente revela um passado não muito distante vivido pela sociedade amazonense.

Revista Eletrônica da ANPHLAC, ISSN 1679-1061, n. 16, p. 85 - 114, Jan./Jul. 2014. http://revista.anphlac.org.br 
Mesmo exercendo cargos de relevância em Silves, como vigário, professor e inspetor paroquial, aliado de uns e adversário de tantos outros, o sacerdote por sua cor e condição de liberto sofreu forte oposição política ao tentar ampliar sua esfera de influência. É necessário que se destaque o fato de que sua desqualificação e os ataques sofridos estavam vinculados diretamente à sua cor da pele e ao fato de ser este indivíduo um liberto.

Muitas perguntas a respeito da atuação do padre Daniel Marques de Oliveira ficam em aberto: sua aproximação com a igreja católica e seu ingresso no clero fazia parte de uma estratégia de mobilidade social para romper com a "mácula do defeito de cor”. Mesmo na possibilidade de acreditarmos em tal hipótese padre Daniel, não estava isolado socialmente, na medida em que construiu uma rede de relações sociais e políticas que lhe garantiram relativo sucesso em seus objetivos. Tais estratégias possibilitaram ascensão social para sua mãe? Ex-escrava, mulata, com um filho culto e padre?

Padre Daniel não era apenas pardo o que demonstra as possibilidades de inserção social de indivíduos ligados a experiência do cativeiro, era filho de um branco com uma mulata, portanto, biologicamente era mestiço e utilizava a educação como possibilidade de mobilidade social estendida as populações do interior do Amazonas.

A miscigenação, portanto, aqui, ultrapassa o fator meramente biológico, ganha contornos sociais e culturais, pois revela a tentativa de construção da identidade dos indivíduos de origem africana, que tratados como estrangeiros, marginalizados e intrusos, criaram mecanismos para ingressar no "grêmio da sociedade" seja pelo mundo do trabalho, seja pelo aceite aos padrões culturais do século XIX.

\section{Conclusão}

Sobre o padre Daniel há muito mais para dizer. De início, é preciso salientar o fato de que se trata do primeiro negro de origem escrava a ocupar o cargo de deputado provincial e, tempo depois, de vice-presidente da Assembleia do Amazonas, nas legislaturas de 1876-77. Desconhecemos caso semelhante em todo o Império Brasileiro.

Revista Eletrônica da ANPHLAC, ISSN 1679-1061, n. 16, p. 85 - 114, Jan./Jul. 2014. http://revista.anphlac.org.br 
Mais do que isso, o que contamos aqui de sua história é suficiente para lembrar algo importante: revela-se a densidade histórica de um passado recente vivido pela sociedade amazonense pautado pela discriminação em bases raciais. Apesar da grande influência em Silves, aliado às principais autoridades daquela localidade (acusadas de acoutar escravos fugidos), Daniel sofreu forte oposição das elites políticas de Manaus quando tentava abranger sua esfera de atuação política. No cerne das acusações e desqualificações que sofreu estava a cor de sua pele e o fato de ter sido escravo, ainda que libertado na pia batismal.

Apesar do que afirmava o Novo Testamento, dizia o editor do jornal $O$ Catechista, "no Brasil o fato é que nem todos são livres". Vale acrescentar: muitos, inclusive, viviam um cativeiro ilegal. Também não ajudou o argumento de que fora libertado no ato do batismo. Ainda restava o preconceito de cor. Como sugeria uma das crônicas jornalísticas citadas, ser negro no Amazonas significava possuir uma mancha inextirpável. Implicava, por outro lado, a definição de uma identidade estrangeira para os de origem africana, os tais "intrusos" - discursos de interesse que buscavam marginalizar (e silenciar) negros e negras da vida pública e do seio das questões políticas, sociais e outros mais "assuntos amazonenses".

\section{Fontes}

Jornais: Centro de Documentação e Apoio à Pesquisa - CENDAP/Acervo de Microfilmes - Estrella do Amazonas (1859-1860); O Catechista (1863)

\section{Falas e Relatórios:}

Arquivo Público do Estado do Amazonas - Livros de Ofícios remetidos pela Câmara Municipal de Vila Bela 1873. Disponível em: http://brazil.crl.edu.memoria.bn.br/hdb/periodo.aspx. Acesso em novembro de 2013.

\section{Anais da Assembleia Legislativa}

Anais da Assembleia Legislativa do Amazonas de 1870-1871. Manáos: Impresso na Typographia Industrial, p. 02-04, 1882.

Anais da Assembleia Legislativa do Amazonas do biênio 1872-1873. Manáos: Impresso na Typographia, do Amazonas, p. 02-04, 1882. Disponível em: http://www.aleam.gov.br/Legislacao_1871_1889. Acesso em novembro de 2013. 


\section{Referências Bibliográficas}

CHALHOUB, Sidney. Trabalho, lar e botequim: o cotidiano dos trabalhadores no Rio de Janeiro da Belle Époque. São Paulo: Brasiliense, 1986.

COSTA, Sérgio. A mestiçagem e seus contrários - Etnicidade e nacionalidade no Brasil contemporâneo.Tempo Social. S. Paulo, 13(1), maio de 2001, p. 143-158.

CRUZ, Heloísa de Faria."Na Oficina do Historiador: Conversas sobre História e Imprensa". Projeto História, São Paulo, n 35, 2007.

GRUZINSKI, Serge. O Pensamento mestiço. São Paulo: Companhia das Letras, 2001 MATTOS, Hebe Maria. Escravidão e cidadania no Brasil Monárquico. $2^{\mathrm{a}}$. Ed. - Rio de Janeiro: Jorge Zahared. 2004.

MUNANGA, Kabengele. Mestiçagem e identidade afro-brasileira. In: OLIVEIRA, Iolanda (org). Cadernos PENESB 1 - relações raciais e educação: alguns determinantes. Niterói: UFF, Intertexto, 1999.

NETO, Provino Pozza. Alforrias escravas na Província do Amazonas. In: O fim do silencio: presença negra na Amazônia. Belém: Editora Açaí, 2011.

OLIVEIRA, Anderson José Machado de. Devoção Negra: santos pretos e catequese no Brasil colonial. Rio de Janeiro: Quartet/Faperj, 2008

PESAVENTO, Sandra Jatahy. Uma outra cidade: o mundo dos excluídos no final do século XIX. 1 $1^{\mathrm{a}}$. ed. São Paulo: Editora Nacional, 2001.

SANTOS, F. J. [et alli]. Cem anos de Imprensa no Amazonas: catalogo de jornais (1851-1950). $2^{a}$ ed. Revisada. Manaus: Ed. Umberto Calderaro, 1990.

SCHWARCZ, Lilia M. Retrato em Branco e Negro: jornais, escravos e cidadãos em São Paulo no final do século XIX. São Paulo: Companhia das Letras, 2008.

THOMPSON, Edward Palmer. A Miséria da Teoria ou um Planetário de Erros: Uma crítica ao pensamento de Althusser. Rio de Janeiro: Zahar, 1981.

THOMPSON, Edward Palmer. Costumes em Comum: estudos sobre a cultura popular tradicional. São Paulo: Cia das Letras, 1998.

THOMPSON, Edward Palmer. A formação da classe operária. Rio de Janeiro: Paz e Terra, 2004.

UGARTE, Maria Luiza Pinheiro. Folhas do Norte. Letramento e periodismo no Amazonas (1880-1920). PUC-SP Tese de doutorado. São Paulo 2001.

Revista Eletrônica da ANPHLAC, ISSN 1679-1061, n. 16, p. 85 - 114, Jan./Jul. 2014.

http://revista.anphlac.org.br 
Revista Eletrônica da ANPHLAC, ISSN 1679-1061, n. 16, p. 85 - 114, Jan./Jul. 2014. http://revista.anphlac.org.br 